\title{
VOTOS DISSONANTES: A DESARMONIA NAS DECISÕES COLEGIADAS DO SUPREMO TRIBUNAL FEDERAL
}

\author{
WHEN JUSTICES GO OFF PITCH: THE LACK OF HARMONY IN DECISIONS OF THE \\ BRAZILIAN SUPREME COURT
}

\section{VOTOS DISONANTES: LA DESARMONÍA EN LAS DECISIONES COLEGIADAS DEL SUPREMO TRIBUNAL FEDERAL}

\section{Sandro Luís Tomás Ballande Romanelli ${ }^{1}$}

Licença CC BY:

Artigo distribuído sob os termos Creative Commons, permite uso e distribuição irrestrita em qualquer meio desde que $o$ autor credite a fonte original.

\begin{abstract}
Resumo: Este artigo trata da deliberação no Supremo Tribunal Federal a partir da descrição de seu processo decisório. Procura-se demonstrar que o processo deliberativo do STF tem sido insuficiente para harmonizar os debates de seus 11 ministros, resultando num inevitável impasse. Inicialmente são detalhadas as regras institucionais que atribuem poderes ao relator (como o poder de agenda e de elaboração da ementa) e que organizam as sessões de julgamento e a formação do acórdão. Segue-se uma análise de seus efeitos, destacando as incongruências entre o que consta nos acórdãos e o que de fato restou documentado nas transcrições dos debates e votos individuais dos membros do Tribunal em dois processos relacionados, a ADPF 130 e a Reclamação 9.428/DF.
\end{abstract}

Palavras-chave: Supremo Tribunal Federal, processo decisório, acórdãos, deliberação.

Abstract: This article describes the decision making and deliberation process of the Brazilian Supreme Court (STF). It seeks to demonstrate that the deliberative performance of the STF has been insufficient to harmonize the debates of its eleven judges, resulting in an inevitable stalemate. The paper addresses the detailed institutional rules that give powers to the rapporteur (such as the power of agenda and the elaboration of the summary), and that organize the sessions of the court and the formation of the agreement. A case study of two related processes (ADPF 130 and Reclamação 9.428/DF) highlights inconsistencies between what is shown in the agreements and what actually occurred in the trial sessions, as documented in the transcripts of the debates and votes of the individual members of the Court.

Keywords: Brazilian Supreme Court, decision making, rulings, deliberation.

1 Doutor em Direito Público (UFPR), pesquisador do Grupo de Direito e Política (DIRPOL-UFPR) e professor do IFPR Campus Cascavel, Paraná, Brasil, sromanelli@gmail.com. 
Resumen: Este artículo trata de la deliberación en el Supremo Tribunal Federal a partir de la descripción de su proceso decisorio. Se busca demostrar que el proceso deliberativo del STF ha sido insuficiente para armonizar los debates de sus 11 ministros, resultando en un inevitable impasse. Inicialmente son detalladas las reglas institucionales que atribuyen poderes al relator (como el poder de agenda y de elaboración de ementa) y que organizan las sesiones de sentencia y la formación de acuerdos. Sigue un análisis de sus efectos, destacando las incongruencias entre lo que consta en los acuerdos y lo que de hecho está documentado en las transcripciones de los debates y votos individuales de los miembros del Tribunal en dos procesos relacionados, la ADPF 130 y la Reclamación 9.428/DF.

Palabras clave: Supremo Tribunal Federal, proceso decisorio, acuerdos, deliberación.

\title{
INTRODUÇÃO
}

\begin{abstract}
"Aqui não há individualidade nenhuma. (...) Já sabemos o resultado que, para mim, não foi 6 a 5. Houve uma decisão do Tribunal do qual eu faço parte; e não sou senão um pedaço deste Tribunal. (...) Não precisamos ficar discutindo quem ganhou, quem perdeu. Quem ganhou foi o Tribunal todo."
\end{abstract}

As frases em epígrafe foram proferidas há mais de dez anos pelo ex-Ministro Eros Grau no julgamento da Ação Direta 3510, que debateu a constitucionalidade do artigo $5^{\circ}$ da Lei de Biossegurança (Lei 11.105/2005, que regulamentou a utilização de células-tronco embrionárias em pesquisas científicas).

Após três anos de análise, o Supremo Tribunal Federal (STF) decidiu então pela improcedência da ADI n. 3510 por seis votos a cinco. Embora a constitucionalidade da lei tenha sido obtida por exígua maioria, ${ }^{3}$ a manifestação do Ministro Eros Grau demonstrava, além de louvável desprendimento, a visão de um ideal: Um tribunal no qual seus integrantes deliberariam abertamente sobre os melhores argumentos para, ao final, acolher a tese vencedora como manifestação da coletividade, superando suas divergências em prol da unidade.

Embora bela e sedutora, tal visão não se confirma quando se observam algumas das manifestações escritas e orais dos ministros no Supremo Tribunal Federal.

Neste artigo, procura-se descrever a performance deliberativa do processo decisório no STF, indicando com especial destaque as incongruências entre o que consta nos acórdãos e o que de fato restou documentado nas transcrições dos debates e votos individuais dos membros do Tribunal.

Ao contrapor os longos debates orais e incontáveis votos individuais aos acórdãos finais e suas ementas, o que emerge é uma corte cindida, cujos debates aprofundam divergências, sem agregar,

2 Manifestação do Ministro Eros Grau. STF: ADI 3510/DF, Rel. Min. Carlos Britto, julgamento em 29.05.2008, fls. 655-656.

Carlos Ayres Britto, Ellen Gracie, Cármen Lúcia, Joaquim Barbosa, Marco Aurélio e Celso de Melo decidiram pela improcedência sem ressalvas, somando seis votos contra cinco que julgavam a Ação Direta parcialmente procedente: Cezar Peluso, Gilmar Mendes, Carlos Alberto Menezes Direito, Ricardo Lewandowski e Eros Grau. 
com raras exceções, argumentos para fortalecer a tese vencedora. Poucos são os autores ${ }^{4}$ que tratam especificamente dos procedimentos deliberativos utilizados no STF, embora a corte tenha práticas peculiares, seja pela vasta gama de partícipes e debatedores nas audiências públicas ou ainda pela amplitude dos debates na mídia.

Nessa polifonia de vozes dissonantes, falta aos acórdãos algo que Ihes traga harmonia que pudesse servir como opinião da corte.

Para defender este ponto de vista, transcrevem-se votos escritos e orais proferidos nos julgamentos da Ação de Descumprimento de Preceitos Fundamentais (ADPF) 130 e da Reclamação 9.428, bem como de dados secundários, utilizando-se dos competentes levantamentos realizados por Guilherme Klafke, Marcela Mattiuzzo e Saylon Pereira na Escola de Formação da Sociedade Brasileira de Direito Público. ${ }^{5}$

Retornando à tônica do debate, procura-se demonstrar que o processo deliberativo do STF tem sido insuficiente para harmonizar os cantos e contracantos de seus 11 ministros, resultando numa inevitável música dissonante.

\section{COMPONDO ACÓRDÃOS: AS REGRAS DA HARMONIA}

\subsection{CONTRAPONTO A ONZE VOZES}

Na teoria musical, contraponto ${ }^{6}$ é uma técnica de composição na qual diversas vozes interagem harmonicamente, embora mantendo ritmo e forma independentes.? No STF, as onze vozes que formam as decisões colegiadas no plenário obedecem a um rito e seguem procedimentos que deveriam, no plano ideal, levar a uma decisão da corte. A decisão seria, assim, fruto da depuração de argumentos contrapostos em um debate que leva à melhor solução jurídica. Mas, no debate que ocorre na fase de deliberação, a forma é inseparável do resultado. Como se verá adiante, o acórdão surge na sequência de falas dos ministros, de forma análoga aos cantos e contracantos que criam a harmonia de uma sinfonia. É no curso do debate que a decisão toma corpo, sustentada nas justificativas que fundamentam a decisão tomada e afastam outras soluções descartadas pela corte.

4 Honrosa exceção, com excelentes estudos sobre a qualidade dos debates no STF, são os pesquisadores José Rodrigo Rodriguez e Conrado Hübner Mendes. Também já abordaram o assunto Oscar Vilhena Vieira e Virgílio Afonso da Silva. Entre os grupos de estudo que se dedicam ao tema, cumpre indicar a notável contribuição da Sociedade Brasileira de Direito Público, na qual os egressos de sua escola de formação produziram uma dezena de competentes monografias sobre o tema da deliberação no STF, três delas amplamente utilizadas neste trabalho, de Guilherme Klafke, de Marcela Mattiuzzo e de Saylon Pereira.

5 Restringiu-se o escopo da pesquisa apenas a acórdãos em julgamentos do controle concentrado de constitucionalidade (ADI e ADPF). Tais pesquisas incluíram dados dos julgamentos ocorridos de outubro de 1988 a junho de 2010, colhidos por Guilherme Klafke, Marcela Mattiuzzo e Saylon Pereira. Entretanto, sinaliza-se que uma interessante pesquisa a ser feita seria a atualização dos dados para fins de 2013 , a verificar se a dinâmica decisória do STF sofreu alterações.

6 Como explica Lívio Tragtenberg (2002, p. 15): "O termo contraponto deriva do latim punctus contra punctum, nota contra nota, ou ainda melodia contra melodia. Trata, portanto, de sons que se contrapõem simultaneamente. Basicamente, contraponto é direcionamento melódico."

7 TRAGTENBERG, Lívio. Contraponto: uma arte de compor. 2. ed. São Paulo: EdUSP, 2002, p. 20. 
Esmiuçar os debates nas sessões plenárias do STF para observar de perto sua liturgia e seus ritos não é simples curiosidade ou crônica de bastidores. Este trabalho parte do pressuposto que, sendo as decisões do STF relevantes para a democracia brasileira, a forma como essas decisões são tomadas tem influência direta na estabilidade de nosso regime. Nesse sentido, a legitimidade da jurisdição constitucional como instituição representativa reside na qualidade das boas justificativas resultantes do processo decisório, conforme a tese de doutoramento de Conrado Hübner Mendes:

Se a legitimidade democrática não se limita à agregação de interesses individuais, mas deve abranger decisões dotadas de boas justificativas compartilhadas por todos, conforme propõem teorias da democracia deliberativa, instituições políticas devem ser capazes de dar conta dessa dupla demanda. Por essa razão, o parlamente eleito é representativo somente no primeiro aspecto da legitimidade. A corte é o candidato principal para cumprir a segunda demanda. Deve ser entendida como instituição representativa porque é mais sensível a razões, e não a desejos majoritários. Se, por um lado, não representa indivíduos particulares, por outro, participa de um processo altamente argumentativo onde as razões de todas as partes potencialmente interessadas são ouvidas. ${ }^{8}$

Diante disso, o estudo da forma na qual o STF debate, delibera e expõe suas decisões colegiadas é sobremaneira relevante para a legitimidade da instituição e a estabilidade da democracia brasileira.

No entanto, como destaca José Rodrigo Rodriguez, o atual debate sobre reforma do poder judiciário "está mais centrado em debates gerenciais sobre a celeridade do judiciário e sua capacidade de gerar segurança jurídica do que na qualidade intrínseca da prestação jurisdicional". Os temas do processo decisório colegiado e da racionalidade da atuação dos magistrados estão habitualmente fora da pauta, o que, como indica Rodriguez, "pode transformar o debate sobre a reforma do judiciário (...) em uma discussão que exclui o direito de seu campo de preocupações". 9

Arnold Schoenberg, aclamado compositor e autor de um dos mais influentes livros de teoria musical do século XX, ensinava que o estudo da harmonia englobava os "complexos sonoros (acordes) e de suas possibilidades de encadeamento, tendo em conta seus valores arquitetônicos, melódicos e rítmicos e suas relações de equilíbrio [Gewichtsverhältnisse]." 10 Para Schoenberg, ainda que um compositor desejasse compor música contemporânea, liberta das formas clássicas, o domínio das regras de harmonia seria fundamental para seu sucesso.

Nessa toada, as regras do processo decisório do Plenário do STF são fundamentais para compreender o encadeamento dos votos dos ministros e, talvez assim, explicar o descompasso entre as ementas, os acórdãos e os debates orais.

8 MENDES, Conrado Hübner. Direitos fundamentais, separação de poderes e deliberação. Tese (doutorado) em Ciência Política. São Paulo: USP, 2008, p. 68-69.

9 RODRIGUEZ, José Rodrigo. Sobre a Qualidade da Jurisdição: Fundamentação das Sentenças, Justiça Opinativa e Luta pela Justificação no Direito Brasileiro Contemporâneo. Texto apresentado no Núcleo de Constitucionalismo e Democracia do Programa de Pós-Graduação em Direito da UFPR, 2011, p. 3.

10

SCHOENBERG, Arnold. Harmonia. Trad. Marden Maluf. São Paulo: Unesp, 2001, p. 49. 
Assim como regras podem levar à harmonia, da mesma forma procedimentos podem incentivar o descompasso. É o que parece ocorrer no STF.

\subsection{EM PAUTA: O REGIMENTO INTERNO}

O processo decisório do Supremo Tribunal Federal é disciplinado pela Lei n. 9.868/99 e pelo seu Regimento Interno (RISTF). Embora para muitos processos ${ }^{11}$ a corte trabalhe dividida em duas turmas de cinco membros (art. $4^{\circ}$ ), descrevem-se aqui os procedimentos do tribunal pleno, órgão responsável pelo julgamento do controle de constitucionalidade em abstrato (art. 97, CF/88). ${ }^{12}$

Protocolada uma ação de controle de constitucionalidade em abstrato, ${ }^{13}$ os autos são remetidos ao Presidente do STF para que este designe o ministro Relator (art. 60 do RISTF). ${ }^{14}$

Porém, ao contrário de outras Cortes, como a austríaca, a italiana e a alemã ${ }^{15}$, o Presidente não indica livremente o Relator. Este é escolhido (art. 66) ${ }^{16}$ de forma aleatória mediante sorteio eletrônico entre 10 dos 11 membros do Tribunal, excetuando-se o Presidente (art. 67). ${ }^{17}$ No sistema do STF, não há como direcionar casos selecionados de acordo com a especialização de cada ministro ou assuntos de predileção.

\subsubsection{Poderes do Ministro Relator}

Ao ministro relator incumbe executar uma ampla gama de atos de administração do processo, listados nos 20 incisos do art. 21 do RISTF. Ainda, as Leis que disciplinam os processos no controle abstrato de constitucionalidade (Lei n. 9.868/99 para ADIs e ADCs, e Lei n. 9.882/99 para ADPF) atribuem ao relator inúmeras questões procedimentais, como, por exemplo, indeferir liminarmente a petição inicial, ${ }^{18}$ conceder pedidos cautelares em período de recesso, ${ }^{19}$ admitir amici curiae,${ }^{20}$ requisitar informações ${ }^{21}$ e convocar audiências públicas e peritos..$^{22}$

11 O STF é um tribunal que acumula muitas funções. Além de atuar no controle de constitucionalidade, o tribunal também atua recebendo inúmeros recursos (ordinários e extraordinários), agravos de instrumento, Habeas Corpus e seus recursos, reclamações e ainda ações de competência originária, conforme descrito nos incisos I e II do art. 102 da CF/88. Tal diversidade de funções explica o número assombroso de mais de 10.000 decisões proferidas em 2012 e mais de 11.000 em 2013.

12 CF/88, art. 97: Somente pelo voto da maioria absoluta de seus membros ou dos membros do respectivo órgão especial poderão os tribunais declarar a inconstitucionalidade de lei ou ato normativo do Poder Público.

13 São de controle de constitucionalidade em abstrato as Ações Diretas de Inconstitucionalidade (ADIs ordinárias e interventivas ou por omissão), as Ações Declaratórias de Constitucionalidade (ADCs) e as Arguições de Descumprimento de Preceito Fundamental (ADPF), previstas na CF/88, art. 102, I, 'a' e seu $\$ 1^{\circ}$.

14 RISTF, art. 60: Com ou sem o preparo, os autos serão distribuídos ao Relator ou registrados à Presidência, de acordo com a respectiva competência, salvo os casos definidos neste Regimento.

15 KLAFKE, Guilherme Forma. Vícios no processo decisório do Supremo Tribunal Federal. Monografia (especialização) em Direito Público. São Paulo: SBDP, 2010, p. 11 e tabela de p. 172.

16 RISTF, art. 66: A distribuição será feita por sorteio ou prevenção, mediante sistema informatizado, acionado automaticamente, em cada classe de processo. $\S 1^{\circ} \mathrm{O}$ sistema informatizado de distribuição automática e aleatória de processos é público, e seus dados são acessíveis aos interessados. $\S 2^{\circ}$ Sorteado o Relator, ser-lhe-ão imediatamente conclusos os autos.

17 RISTF, art. 67: Far-se-á a distribuição entre todos os Ministros, inclusive os ausentes ou licenciados por até trinta dias, excetuado o Presidente.

18 Arts. $4^{\circ}$ e 15 da Lei n. $9.868 / 99$ e art. $4^{\circ}, \S 2^{\circ}$ da Lei n. 9.882/99.

19 Art. $10, \S 1^{\circ}$ da Lei n. $9.868 / 99$ e art. $5^{\circ}, \S \S 1^{\circ}$ e $2^{\circ}$ da Lei n. $9.882 / 99$

20 Art. $7^{\circ}, \$ 2^{\circ}$ da Lei n. $9.868 / 99$.

21 Arts. $6^{\circ}, 9^{\circ}, \S 1^{\circ}$ e $20, \S \S 1^{\circ}$ e $2^{\circ}$ da Lei n. 9.868/99 e art. $6^{\circ}$, caput da Lei n. 9.882/99.

22 Art. $9^{\circ}, \S \S 1^{\circ}, 2^{\circ}$ e $3^{\circ}$; art. $20, \S \S 1^{\circ}, 2^{\circ}$ e $3^{\circ}$ da Lei n. $9.868 / 99$; art. $6^{\circ}, \S 1^{\circ}$ da Lei n. 9.882/99. 
Dentre os poderes do relator, três atribuições são especialmente relevantes para este estudo:

a) Elaborar o relatório: Ao relator incumbe, logicamente, relatar o feito para os demais ministros, distribuindo antecipadamente cópias do relatório para cada ministro (art. 87) ${ }^{23}$. No relatório são narrados os fatos relevantes do caso, bem como os pedidos, os seus fundamentos jurídicos, as manifestações das partes e terceiros (defesa, informações, manifestações do Ministério Público e amici curiae), destacando quais os pontos centrais a serem decididos pelo Tribunal;

b) Poder de agenda24: Consiste na atribuição exclusiva do relator de pedir dia para julgamento (art. 21, X)25. Cabe somente ao relator informar ao presidente que seu voto está pronto e que o caso pode ser incluído na pauta de uma sessão de debate e julgamento em plenário;

c) Proferir o primeiro voto na sessão de julgamento: Na sessão de julgamento, lido o relatório, ouvidas as sustentações orais e feitos os debates, o julgamento propriamente dito é iniciado com a leitura do voto do relator (art. 135). ${ }^{26}$

O fato de expor seu voto em primeiro coloca o ministro relator em vantagem argumentativa. Os argumentos do voto acabam se tornando um leitmotiv ${ }^{27}$ introduzindo o tema melódico que será, necessariamente, debatido pelos demais ministros. Como constatou Guilherme Klafke ${ }^{28}$, uma vez apresentada a óptica do relator na narração sobre os fatos e na interpretação sobre o direito, as manifestações posteriores podem concordar, discordar ou ainda introduzir uma terceira via (trazendo fatos e interpretações ainda não abordados pelo relator).$^{29}$

23 RISTF, art. 87: Aos Ministros julgadores será distribuída cópia do relatório antecipadamente: I - nas representações por inconstitucionalidade ou para interpretação de lei ou ato normativo federal ou estadual.

24 O poder de agenda, no tocante à escolha do momento correto para realizar a votação (de acordo com articulações políticas), é determinante para a aprovação ou reprovação de um projeto legislativo (cf. AMORIM NETO, Octavio; COX, Gary W. \& MCCUBBINS, Mathew D. Agenda Power in Brazil's Câmara dos Deputados, 1989-98. World Politics, v. 55, n. 4, p. 550-578, 2003.). Embora a hipótese não tenha sido testada empiricamente no STF, o presente trabalho parte da premissa que os ministros relatores têm preferência em sustentar a tese jurídica vencedora e, para isso, podem especular sobre a tendência dos demais ministros e aguardar o momento oportuno para levar um feito ao plenário para julgamento, seja pela alteração de composição na corte, seja pela repercussão do caso na mídia, maximizando suas possibilidades de sucesso.

25 RISTF, art. 21: São atribuições do Relator (...)X - pedir dia para julgamento dos feitos nos quais estiver habilitado a proferir voto, ou passá-los ao Revisor, com o relatório, se for o caso. Também nas leis que regem ADIs, ADCs e ADPFs, o relator "lançará o relatório, com cópia a todos os Ministros, e pedirá dia para julgamento" (Art. $9^{\circ}$, caput, e art. 20, caput, da lei 9.868/99 e art. $7^{\circ}$, caput, da Lei n. 9.882/99).

26 RISTF, art. 135: Concluído o debate oral, o Presidente tomará os votos do Relator, do Revisor, se houver, e dos outros Ministros, na ordem inversa da antiguidade. $\S 1^{\circ}$ Os Ministros poderão antecipar o voto se o Presidente autorizar. § $2^{\circ}$ Encerrada a votação, o Presidente proclamará a decisão. $\S 3^{\circ} \mathrm{Se}$ o Relator for vencido, ficará designado o Revisor para redigir o acórdão. $\S 4^{\circ}$ Se não houver Revisor, ou se este também tiver sido vencido, será designado para redigir o acórdão o Ministro que houver proferido o primeiro voto prevalecente.

27 Leitmotiv, do alemão, "motivo condutor", é expressão comum da análise musical e literária. No universo da música, foi cunhada por Richard Wagner como uma técnica de composição, na qual uma frase ou fórmula musical é repetida ao longo da obra e serve de referência para seu desenvolvimento. METZLER, J. B. Musik um uns: Für den Kursunterricht in Klasse 11. 2. ed. Stuttgart: Poeschel Verlag, 1991, p. 102.

28 KLAFKE, Guilherme Forma. Vícios no processo decisório do Supremo Tribunal Federal. Monografia (especialização) em Direito Público. São Paulo: SBDP, 2010, p. 86.

29 Como afirma Guilherme Klafke, após analisar 66 votos em 7 julgamentos de controle abstrato de constitucionalidade, "no que diz respeito especificamente às questões a serem tratadas na sessão, impressiona a força do ministro relator para pautar as discussões. Dos sete casos, em dois deles a Corte só discutiu pontos tratados pelo relator em seu voto, enquanto em outros três mais da metade dos assuntos foram levantados por ele." 


\subsubsection{DeliberaçÃo: Presto, ma non troppo ${ }^{30}$}

A cadência da deliberação está prevista no regimento interno. Este é rigoroso no controle do uso da palavra: Limita cada ministro a se pronunciar apenas duas vezes sobre o assunto em discussão, com direito a uma manifestação extra, caso queira explicar a modificação do voto (art. 133). ${ }^{31}$ Ainda, o mesmo artigo proíbe a fala de quaisquer ministros sem a autorização do Presidente e veda as interrupções de quem estiver usando a palavra, salvo para apartes devidamente concedidos.

As normas regimentais preveem ainda um julgamento rápido: Depois de lido o relatório e de ouvida eventual sustentação oral por parte de patronos das partes, há a tomada de votos de cada um dos ministros e o julgamento se inicia e termina na mesma sessão (art. 139).

Entretanto, tais esforços regimentais para um julgamento rápido são, na prática, contornados por meio do pedido de vista dos autos. Prerrogativa de quaisquer dos ministros que esteja participando do julgamento, o pedido de vista suspende o julgamento até que o processo seja apresentado novamente em pauta.

Embora o regimento interno determine que o processo seja reapresentado ao plenário até a segunda sessão ordinária subsequente (art. 134), ,32 tal regra é frequentemente ignorada pelos ministros, ${ }^{33}$ como no exemplo colhido por Guilherme Klafke na ADI 1864/PR:

(...) o período de tempo que separa uma sessão de julgamento da outra, após um pedido de vista, pode se estender por anos. Apenas para exemplificar, a primeira sessão para julgar o Caso do PARANAEDUCAÇÃO (ADI 1864/PR) ocorreu em 12.04.2004. O caso só foi retomado em 08.08.2007, três anos e quatro meses depois. ${ }^{34}$

Ainda sobre os votos-vista, a despeito do largo tempo que consomem, raramente inauguram divergências ou divergem da opinião da maioria já formada. É o que demonstra o extenso levantamento elaborado por Saylon Pereira, no qual praticamente $70 \%$ dos 73 votos-vista realizados no STF no período de 05.10 .1988 a 30.06.2010 integraram a corrente vencedora:

$30 \quad$ Notação musical para andamento: rápido, mas não muito.

31 RISTF, art. 133. Cada Ministro poderá falar duas vezes sobre o assunto em discussão e mais uma vez, se for o caso, para explicar a modificação do voto. Nenhum falará sem autorização do Presidente, nem interromperá a quem estiver usando a palavra, salvo para apartes, quando solicitados e concedidos. Parágrafo único. Os apartes constarão do acórdão, salvo se cancelados pelo Ministro aparteante, caso em que será anotado o cancelamento (Emenda Regimental 40/2010).

32 RISTF, art. 134. Se algum dos Ministros pedir vista dos autos, deverá apresentá-los, para prosseguimento da votação, até a segunda sessão ordinária subsequente. $\S 1^{\circ}$ Ao reencetar-se o julgamento serão computados os votos já proferidos.

33 O tema já teve grande repercussão na mídia e foi objeto da Resolução $n^{\circ}$. 278, de 2003. Nela, o ministro Maurício Corrêa, presidente do STF à época, estabelecia que o Ministro que pedir vista dos autos deverá devolvê-los no prazo de 10 (dez) dias, contados da data que os receber em seu Gabinete, prazo prorrogável uma única vez, sendo que caso fosse esgotado o prazo da prorrogação, o Presidente do Tribunal ou da Turma requisitará os autos e reabrirá o julgamento do feito na segunda sessão ordinária subsequente, com publicação em pauta. Ainda, a resolução atribuía às Coordenadorias de Sessões o controle rigoroso dos processos e dos prazos ora estabelecido, devendo entregar ao respectivo Presidente, a cada sessão, relatório circunstanciado a respeito. $\left(\S 5^{\circ}\right.$ do art. $\left.1^{\circ}\right)$. Entretanto, como a resolução, ainda em vigor, não prevê quaisquer sanções ou penalidades, tornou-se regra inócua para coibir longos atrasos nos julgamentos.

34 KLAFKE, Guilherme Forma. Vícios no processo decisório do Supremo Tribunal Federal. Monografia (especialização) em Direito Público. São Paulo: SBDP, 2010, p. 110. 
Observando o universo pesquisado, os dados mostram que em quase $69 \%$ (cinquenta pedidos) das ações, os votos-vista estavam entre os votos vencedores, somente em aproximadamente $22 \%$ (dezesseis pedidos) eles acabaram derrotados e em pouco mais de $9 \%$ dos casos (sete pedidos) a ação foi considerada prejudicada de alguma forma, ocasionando na ausência de análise do mérito pelo tribunal..$^{35}$

Se o largo decurso do tempo nos votos-vista tem pouco ou nenhum efeito para alterar a decisão da corte, ao contrário, como se argumentará adiante, pode-se destacar o prejuízo que causa na impossibilidade de uma efetiva troca de argumentos entre os ministros, eis que é impraticável recordar rapidamente os detalhes de um debate iniciado há anos, como no exemplo da ADI 1864/PR.

Tal fenômeno pode ser estrategicamente aproveitado pelos ministros, quando têm uma posição minoritária a defender, como demonstra a pesquisa de Saylon Alves Pereira sobre os pedidos de vista:

\begin{abstract}
Além disso, cabe ressaltar também que não são raras as disputas entre os ministros envolvendo concepções do direito e entendimentos sobre determinadas matérias. Nesse contexto, os pedidos de vista utilizados sem regulação podem ter também um papel essencial, pois permitirão o controle do tempo da ação possibilitando ao ministro escolher o melhor momento para trazer a discussão, analisar se a composição da Corte lhe é favorável, e, como numa espécie de jogo de xadrez, permitir movimentar estrategicamente o processo, favorecendo-se das características de cada peça para vencer o jogo e consolidar seu entendimento. ${ }^{36}$
\end{abstract}

Por outro lado, inexistindo pedido de vistas dos autos, o julgamento em uma mesma sessão com a imediata decisão não se presta a um "processo deliberativo que se pretenda verdadeiramente coletivo", que venha a ultrapassar a mera "apresentação de votos construídos individualmente nos gabinetes", na opinião partilhada por Guilherme Klafke. ${ }^{37}$

35 PEREIRA, Saylon Alves. Os pedidos de vista no supremo tribunal federal: uma análise quantitativa nos casos de controle concentrado de constitucionalidade. Monografia (especialização) em Direito Público. São Paulo: SBDP, 2010, p. 36-37.

36 PEREIRA, Saylon Alves. Os pedidos de vista no supremo tribunal federal: uma análise quantitativa nos casos de controle concentrado de constitucionalidade. Monografia (especialização) em Direito Público. São Paulo: SBDP, 2010, p. 10.

37 KLAFKE, Guilherme Forma. Vícios no processo decisório do Supremo Tribunal Federal. Monografia (especialização) em Direito Público. São Paulo: SBDP, 2010, p. 110. 


\subsubsection{O SOLO VERSUS TUTTI DAS SESSÕES PÚBLICAS}

Em consonância com os preceitos constitucionais (art. 5 ${ }^{\circ}$ LX e art. 93, IX), ${ }^{38}$ as sessões de julgamento do STF são públicas, salvo quando há segredo de justiça. A regra é reiterada no Regimento Interno (art. 124), ${ }^{39}$ na qual o próprio Plenário (ou Turmas) pode determinar que a sessão seja secreta. Além de feitos sob segredo de justiça (art. 155 do CPC e art. 201, § 6 do CPP), ${ }^{40}$ motivos ordinários para deliberações secretas são a avocação de causas e a intervenção federal.

Para as ações de controle abstrato de constitucionalidade, não há previsões regimentais que determinem sessões secretas. ${ }^{41}$ As sessões públicas e televisionadas, embora saudadas como triunfo da democracia, parecem ter efeitos negativos para a qualidade das deliberações, uma vez que dificulta que se encontre uma síntese na deliberação, um denominador comum capaz de sintetizar a opinião da corte.

Neste sentido, seguem as críticas de Virgílio Afonso da Silva:

O modelo brasileiro pode ser considerado como um modelo extremo de deliberação externa, o que o afasta definitivamente dos modelos continentais europeus. Especialmente devido à (1) quase total ausência de trocas de argumentos entre os ministros: nos casos importantes, os ministros levam seus votos prontos para a sessão de julgamento e não estão ali para ouvir os argumentos de seus colegas de tribunal; (2) inexistência de unidade institucional e decisória: o Supremo Tribunal Federal não decide como instituição, mas como a soma dos votos individuais de seus ministros; e (3) carência de decisões claras, objetivas e que veiculem a opinião do tribunal: como reflexo da inexistência de unidade decisória, as decisões do Supremo Tribunal Federal são publicadas como uma soma, uma colagem, de decisões individuais; muitas vezes é extremamente difícil, a partir dessa colagem, desvendar qual foi a real razão de decidir do tribunal em determinados casos, já que, mesmo os ministros que votaram em um mesmo sentido podem tê-lo feito por razões distintas. (destacado) ${ }^{42}$

$38 \mathrm{CF} / 88$, art. $5^{\circ}, \mathrm{LX}$ - a lei só poderá restringir a publicidade dos atos processuais quando a defesa da intimidade ou o interesse social o exigirem; Art. 93, IX - todos os julgamentos dos órgãos do Poder Judiciário serão públicos, e fundamentadas todas as decisões, sob pena de nulidade, podendo a lei limitar a presença, em determinados atos, às próprias partes e a seus advogados, ou somente a estes, em casos nos quais a preservação do direito à intimidade do interessado no sigilo não prejudique o interesse público à informação.

39 RISTF, art. 124. As sessões serão públicas, salvo quando este Regimento determinar que sejam secretas, ou assim o deliberar o Plenário ou a Turma

40 Código de Processo Civil, art. 155- Os atos processuais são públicos. Correm, todavia, em segredo de justiça os processos: I - em que o exigir o interesse público; II - que dizem respeito a casamento, filiação, separação dos cônjuges, conversão desta em divórcio, alimentos e guarda de menores.

Código de Processo Penal, art. 201, $\S 6^{\circ}$. O juiz tomará as providências necessárias à preservação da intimidade, vida privada, honra e imagem do ofendido, podendo, inclusive, determinar o segredo de justiça em relação aos dados, depoimentos e outras informações constantes dos autos a seu respeito para evitar sua exposição aos meios de comunicação.

41 A realização de sessões de julgamento secretas em cortes constitucionais já foi tema de intenso debate na literatura constitucional norteamericana. $\mathrm{O}$ artigo clássico a respeito, que sintetiza o histórico e as principais correntes (tendo a francesa como exemplo de sessões privadas e a americana, pós Chief Justice Marshall, como modelo de deliberação pública), é o de Kurt H. Nadelmann (1959).

42 SILVA, Virgílio Afonso da. STF, Deliberação, Diálogo e Razão Pública. Revista de Direito Administrativo (RDA), v. 250, p. 197-227, 2009, p. 217-218. 
Virgílio adota a distinção proposta por Ferejohn e Pasquino entre modelos de "deliberação interna" e "deliberação externa". No primeiro, as razões e os argumentos são trocados no interior de um grupo, com o intuito de levá-lo a decidir em uma determinada direção. Já na deliberação externa, o esforço está em convencer atores externos ao grupo. ${ }^{43}$

Neste contexto de deliberação externa, um dos possíveis efeitos da exposição midiática das sessões é o individualismo, somado à indisposição dos ministros de se entregarem ao debate espontâneo. Receosos de serem surpreendidos por um argumento imprevisto, sobre o qual não tenham conhecimento imediato, optam por limitar-se à leitura de seus votos prontos, já previamente redigidos e que, com raras exceções, não fazem sequer menção aos argumentos dos votos dos demais ministros, como aponta o levantamento de Guilherme Klafke:

(...) os votos, em sua maioria, ou não fazem menção a qualquer fundamento contido em outro pronunciamento, ou fazem menções superficiais, dispensáveis ou meramente elogiosas. Não há qualquer interação que contribua para uma opinião da Corte. (...) Levando o argumento às últimas consequências, haveria até 53 votos, dos 66 totais, sem qualquer confronto de ideias com os votos anteriores. Isso evidenciaria um cenário no qual os ministros trabalham sozinhos em seus votos, aderindo à corrente que mais se afina com suas conclusões na sessão de julgamento. Em geral, fazem menções específicas a algum fundamento que esteja em suas decisões, relacionando-o com o voto condutor da corrente em que se inserem. (destacado) ${ }^{44}$

Nesses casos, as sessões de deliberação se transformam em enfadonhas sessões de leitura, satirizadas pelo jornalista Luiz Maklouf Carvalho na descrição de uma sessão de julgamento no STF para a revista Piauí:

O primeiro bocejo foi do ministro José Antônio Dias Toffoli. Com as mãos em concha, sobre a boca. Depois foi Gilmar Mendes, com a proteção de uma das mãos, e por três vezes em menos de dez minutos. Marco Aurélio Mello o seguiu, com dois bocejos. Eles escutavam Ellen Gracie ler um relatório. A voz da ministra tem um timbre agradável, mas sem modulação. Em plenário, à exceção de poucas frases curtas sobre questões pontuais, a ministra nunca fala, só lê. E sempre de maneira monocórdica. ${ }^{45}$

Há ainda os casos menos complexos, nos quais há prévio consenso e os ministros não veem problemas em enfrentar a sessão de votação sem trazer seus votos previamente escritos. Nesses julgamentos, a possibilidade de apresentar votos individuais leva os ministros a repetir os argumentos do relator, sem efetiva contribuição para o debate, como descreve Guilherme Klafke:

43 SILVA, Virgílio Afonso da. STF, Deliberação, Diálogo e Razão Pública. Revista de Direito Administrativo (RDA), v. 250, p. 197-227, 2009, p. 210.

44 KLAFKE, Guilherme Forma. Vícios no processo decisório do Supremo Tribunal Federal. Monografia (especialização) em Direito Público. São Paulo: SBDP, 2010, p. 119

45 CARVALHO, Luiz Maklouf. Data Venia, O Supremo - O Supremo, quousque tandem? Piauí, v. 4, n. 48, p. 34-41, 2010. 
A possibilidade que todos os ministros têm de apresentar um voto individual contribui para a existência de pronunciamentos que se limitam a reafirmar o que já foi dito. Nos casos em que o voto do relator é um dos únicos disponíveis, a linha de raciocínio condutora do julgamento fica muito mais clara (exemplos do Caso da estabilidade excepcional dos servidores públicos estaduais e municipais catarinenses e do caso dos concursos notariais). Essas considerações dependem, evidentemente, da complexidade da matéria, mas podem expor um problema dos votos individuais. ${ }^{46}$

Desta forma, pouca diferença faz a publicidade da sessão, uma vez que o acórdão, embora produzido publicamente, deixa de ser o resultado de deliberação colegiada e passa a ser composto pela soma dos 11 votos dos ministros do STF, seja com argumentos repetidos, seja com argumentos que não se contrapõem, casos que dificultam a obtenção de uma síntese do julgamento.

\subsubsection{ACóRDÃo E EMENTA}

Nos termos do Regimento Interno, a redação do acórdão e da sua ementa são atribuições do Relator, quando for o vencedor, ou do Ministro que houver proferido o primeiro voto da corrente majoritária, quando o Relator for vencido (art. 96, § $\left.4^{\circ}\right) .4^{77}$

O acórdão redigido pelo Relator não substitui os votos dos demais ministros. Isto porque, como indica o Regimento Interno do STF, o áudio do julgamento é transcrito no acórdão (art. 93) ${ }^{48}$ e deve registrar praticamente tudo o que foi debatido nas sessões, incluindo "o relatório, a discussão, os votos fundamentados, bem como as perguntas feitas aos advogados e suas respostas" (art. 96, caput). ${ }^{49}$

Desta forma, extremamente pertinente é a crítica feita por Oscar Vilhena Vieira em seu texto

\section{Supremocracia:}

Hoje, o que temos é a somatória de 11 votos (que, em um grande número de casos, já se encontram redigidos antes da discussão em plenário) e não uma decisão da Corte, decorrente de uma robusta discussão entre os Ministros. Isto seria muito importante para que a integridade do Supremo, enquanto instituição colegiada, fosse mantida.

Quando nos perguntamos qual a decisão do Supremo no caso das células-tronco, fica evidente que há uma multiplicidade de opiniões. Mesmo se pegarmos o voto do relator, que foi muito além da questio iuris submetida ao Tribunal, o que dali foi aceito pela maioria e o que não foi aceito? Quais são os efeitos precisos da decisão? Assim, as decisões precisam deixar de ser vistas como uma somatória aritmética de votos díspares. ${ }^{50}$

46 KLAFKE, Guilherme Forma. Vícios no processo decisório do Supremo Tribunal Federal. Monografia (especialização) em Direito Público. São Paulo: SBDP, 2010, p. 88-89.

47 RISTF, art. 96, § $4^{\circ}$. A Secretaria das Sessões encaminhará os autos ao Relator sorteado ou ao Relator para o acórdão, para elaboração deste e da ementa no prazo de dez dias.

48 RISTF, Art. 93. As conclusões do Plenário e das Turmas, em suas decisões, constarão de acórdão, do qual fará parte a transcrição do áudio do julgamento.

49 RISTF, Art. 96: Em cada julgamento a transcrição do áudio registrará o relatório, a discussão, os votos fundamentados, bem como as perguntas feitas aos advogados e suas respostas, e será juntada aos autos com o acórdão, depois de revista e rubricada.

VIEIRA, Oscar Vilhena. Supremocracia. Rev. Direito GV, v.4, n. 2, p. 441-463, 2008. 
Os ministros que participaram do julgamento podem encaminhar, em até 20 dias, os votos escritos para a Secretaria das Sessões, que os anexa ao acórdão. Caso descumprido o prazo, a Secretaria transcreve o áudio incluindo a ressalva de que não houve revisão. ${ }^{51}$ De qualquer modo, somente após terminada a transcrição do áudio dos debates é que os autos serão encaminhados ao Relator (original, ou Relator para o acórdão), a fim de que ele elabore o acórdão e a ementa dentro de 10 dias.

Ao final, a Secretaria elabora o extrato da ata da sessão, contendo informações sucintas sobre a decisão tomada e os nomes dos ministros presentes para o julgamento e sua posição com relação à corrente vencedora.

Este formato de acórdão, extenso, que registra as opiniões individualizadas de cada um dos integrantes da corte, pertence ao modelo conhecido como seriatim, em oposição ao modelo per curiam.

O modelo seriatim, ou seriado, publica o resultado da deliberação na forma de texto composto, registrando as opiniões de cada um dos membros do colegiado. Sua origem remonta aos primórdios da common law, como indica o esclarecedor artigo de André Rufino do Vale:

O modelo de decisão seriatim corresponde à tradição dos órgãos judiciais colegiados do Common Law, como o King's Bench, cujas sessões deliberativas ficaram caracterizadas pelo pronunciamento "em série" (seriatim) dos discursos (speech) individuais de cada juiz, os quais eram dessa forma consignados nos textos das decisões destinados à publicação (published reports). O costume britânico de proferir e publicar decisões na forma de seriatim opinions foi incorporado pela Câmara dos Lordes (House of Lords), que, no exercício da função judicial pela Law Lords - ressalte-se, sempre considerada não muito distinta daquela exercida por um organismo legislativo, como é a House of Lords - por muito tempo manteve a prática de se manifestar através do conjunto das decisões individuais de cada juiz, as opinion of the Lords. ${ }^{52}$

O autor destaca ainda que tal modelo foi adotado pela suprema corte norte-americana até o início do século XIX, sendo alterado a partir de Marshall na posição de Chief Justice, ressaltando o impacto positivo do abandono do formato seriatim para o fortalecimento do controle de constitucionalidade nos EUA:

(...) Um exemplo claro de alteração desse modelo por meio do desenvolvimento de práticas alternativas de deliberação pode ser encontrado na história da Suprema Corte norteamericana. Nos seus primeiros anos de funcionamento - precisamente entre os anos de 1793 e 1800 -, seguindo o costume judicial inglês, a Suprema Corte norte-americana anunciava suas decisões através das seriatim opinions de seus membros. Cada Justice pronunciava seu voto individualmente e o conjunto de todas as opiniões expostas "em série" era assim apresentado ao público. Quando John Marshall se tornou Chief Justice, a

51 Caso os votos entregues na versão escrita não correspondam exatamente ao que foi proferido na sessão que julgou o caso, prevalece a degravação do áudio, como já decidido pelo STF nos Embargos de Declaração da ADI 2581, Rel. Min. Marco Aurélio, j. 15.04.2009.

52 VALE, André Rufino do. É preciso repensar a deliberação no Supremo Tribunal Federal. Revista Consultor Jurídico [on-line], 2014, p. 2. 
Corte passou a adotar a prática de anunciar seus julgamentos em uma single opinion, que dessa forma passava a representar a opinião expressada pela maioria de seus membros. A partir de 1801, os Justices deixaram paulatinamente o costume de proclamar individualmente seus votos e passaram a estar mais comprometidos com a representação da unidade institucional da Corte, através da construção colegiada de uma única decisão, a opinion of the Court, dotada de uma única ratio decidendi. A redação seria então incumbida ao Chief Justice, que no caso era Marshall, mas o texto deveria expressar, em vez de sua posição pessoal, a opinião do colegiado de juízes, o qual teria que falar em uma só voz (speak in one voice). Essa inovação na prática deliberativa dos Justices demonstrou-se crucial para a afirmação da Suprema Corte como unidade institucional em face dos demais Poderes, num contexto político conturbado que marcou os primórdios da república norte-americana, e foi reconhecida posteriormente como um dos grandes feitos da histórica carreira de Marshall. (destacado) ${ }^{53}$

Outro estudo demonstra as dificuldades da decisão seriatim para a formação de fundamentos comuns da decisão entre os ministros nos julgamentos do STF, equivalente à ratio decidendi dos precedentes no sistema da common law.

Trata-se da pesquisa realizada por Adriana de Moraes Vojvodic, Ana Mara França Machado e Evorah Lusci Costa Cardoso sobre os precedentes e o processo decisório no STF. Em seu estudo analítico, as pesquisadoras constataram que a falta de padrões de decisão implica que "cada caso seja decidido sem referência a casos previamente relacionados. Esse contexto pode colaborar para a falta de transparência decisória e para o que pode ser considerado um deficit democrático do STF".54

Eis alguns dos 'problemas' encontrados pelas pesquisadoras na ação direta de inconstitucionalidade 2591-ED/DF, julgada improcedente pelos ministros pela maioria de nove votos a dois:

Consideremos alguns problemas no julgamento. Primeiro, a dificuldade dos próprios ministros em identificar qual é a questão em discussão. Cada ministro decide sobre um ponto e não há a formação de rationes acerca do mesmo problema. Segundo, o ministro relator não consegue identificar quais foram as rationes de seus colegas e, portanto, não consegue identificar qual foi a ratio decidendi do julgamento, considerando somente a sua como prevalecente. Desse modo, não é possível a formação de uma ratio decidendi do Tribunal. Como vimos, o grau de discricionariedade do relator, no momento de redigir a ementa do caso, é muito grande. Nesse caso, se não fossem opostos embargos de declaração à ementa, ela permaneceria não refletindo o julgamento..$^{55}$

Tendo em vista a natureza do acórdão no STF, composto por uma compilação de votos individuais, cumpre à ementa elaborada pelo relator o papel de apresentar uma síntese do julgado.

53 VALE, André Rufino do. É preciso repensar a deliberação no Supremo Tribunal Federal. Revista Consultor Jurídico [on-line], 2014, p. 3.

54 VOJVODIC, Adriana de Moraes; MACHADO, Ana Mara França; CARDOSO, Evorah Lusci Costa. Escrevendo um romance, primeiro capítulo: precedentes e processo decisório no STF. Rev. Direito GV, v. 5, n. 1, p. 21-44, 2009.

55 VOJVODIC, Adriana de Moraes; MACHADO, Ana Mara França; CARDOSO, Evorah Lusci Costa. Escrevendo um romance, primeiro capítulo: precedentes e processo decisório no STF. Rev. Direito GV, v. 5, n. 1, p. 21-44, 2009. 
Infelizmente, esta nem sempre corresponde à síntese precisa da decisão tomada pela corte, como se verá adiante no caso da ADPF 130.

\section{DECOMPONDO ACÓRDÃOS: A ADPF 130 E A RECLAMAÇÃO 9.428/DF}

\subsection{PRELÚDIO: A INCONSTITUCIONALIDADE DA LEI DE IMPRENSA}

Não há liberdade de imprensa pela metade ou sob as tenazes da censura prévia, inclusive a procedente do Poder Judiciário, pena de se resvalar para o espaço inconstitucional da prestidigitação jurídica. ${ }^{56}$

A Arguição de Descumprimento de Preceito Fundamental (ADPF) 57130 foi ajuizada pelo Partido Democrático Trabalhista (PDT) em 19.02.2008, trazendo como fundamento a tese de que a Lei de Imprensa (Lei 5.250/67), em vigor desde os tempos do regime militar, violaria preceitos fundamentais da nova ordem republicana, ${ }^{58} \mathrm{em}$ especial o regime de liberdade de opinião, manifestação e imprensa trazidos na Constituição de 1988. A relatoria da ADPF 130 foi atribuída, por sorteio eletrônico, ao Ministro Carlos Ayres Britto que, três dias mais tarde (21.02.2008), concedeu liminar para suspender diversos dispositivos ${ }^{59}$ da Lei de Imprensa.

Pouco mais de um ano após o ajuizamento, em 01.04.2009 foi apresentado o relatório e iniciado o julgamento. Em apenas duas sessões (01.04.2009 e 30.04.2009), por maioria ${ }^{60}$ de 7 votos a 4, a Corte julgou a Lei de Imprensa integralmente incompatível com a atual ordem constitucional.

Eis a ementa ${ }^{61}$ lavrada pelo Min. Relator da ADPF 130, Carlos Ayres Britto:

EMENTA: ARGUIÇÃO DE DESCUMPRIMENTO DE PRECEITO FUNDAMENTAL (ADPF). LEI DE IMPRENSA. ADEQUAÇÃO DA AÇÃO. REGIME CONSTITUCIONAL DA "LIBERDADE DE INFORMAÇÃO JORNALÍSTICA", EXPRESSÃO SINÔNIMA DE LIBERDADE DE IMPRENSA. A "PLENA" LIBERDADE DE IMPRENSA COMO CATEGORIA JURÍDICA PROIBITIVA DE QUALQUER TIPO DE CENSURA PRÉVIA. A PLENITUDE DA LIBERDADE DE IMPRENSA COMO REFORÇO OU SOBRETUTELA DAS LIBERDADES DE MANIFESTAÇÃO DO PENSAMENTO, DE INFORMAÇÃO E DE EXPRESSÃO ARTÍSTICA, CIENTÍFICA, INTELECTUAL E COMUNICACIONAL. LIBERDADES QUE DÃO CONTEÚDO ÀS RELAÇÕES DE IMPRENSA E QUE SE PÕEM COMO SUPERIORES BENS DE PERSONALIDADE E MAIS DIRETA EMANAÇÃO DO PRINCÍPIO DA DIGNIDADE

56 Voto do Ministro Carlos Britto. STF: ADPF 130/DF, Rel. Min. Carlos Britto, voto proferido em 01.04.2009, fls. 04. Julgamento finalizado em 30.04.2009.

57 Como a Lei de Imprensa (5.250/67) já existia anteriormente à promulgação da Constituição de 1988, não é adequado pela legislação processual questionar sua (in)constitucionalidade pela via da Ação Direta (ADI ou ADC). Para casos como o da Lei de Imprensa, o instrumento processual previsto é a ADPF: "Caberá (...) arguição de descumprimento de preceito fundamental: I - quando for relevante o fundamento da controvérsia constitucional sobre lei ou ato normativo federal, estadual ou municipal, incluídos os anteriores à Constituição;" (Lei 9.882/99, art. $1^{\circ}$, par. único, destacado).

58 A petição inicial indica a violação aos artigos $5^{\circ}$, incisos IV, V, IX, X, XIII e XIV, e 220 a 223, da CRFB/88.

59 A liminar concedida atingiu mais de 20 artigos da Lei 5.250/67. A liminar foi ainda confirmada pelo plenário do STF em sessão do dia 27.02.2008.

60 Os ministros Eros Grau, Menezes Direito, Cármen Lúcia, Ricardo Lewandowski, Cezar Peluso e Celso de Mello acompanharam o relator, Ministro Carlos Ayres Britto, no sentido da total procedência da ADPF 130 para declarar a íntegra da Lei n $5.250 / 67$ não recepcionada pela CF/88. Os ministros Joaquim Barbosa, Ellen Gracie e Gilmar Mendes se pronunciaram pela parcial procedência da ação, para considerar recepcionados alguns artigos da lei de imprensa. O Ministro Marco Aurélio votou pela total improcedência da ação, mantendo a Lei de Imprensa na íntegra.

61 De acordo com o Regimento Interno, cabe ao Relator sorteado (ou, se este foi voto vencido, ao Relator para o acórdão) redigir a ementa do acórdão, síntese do posicionamento vencedor após os debates (art. 96, § $4^{\circ}$ ). 


\begin{abstract}
DA PESSOA HUMANA. O CAPÍTULO CONSTITUCIONAL DA COMUNICAÇÃO SOCIAL COMO SEGMENTO PROLONGADOR DAS LIBERDADES DE MANIFESTAÇÃO DO PENSAMENTO, DE INFORMAÇÃO E DE EXPRESSÃO ARTÍSTICA, CIENTÍFICA, INTELECTUAL E COMUNICACIONAL. TRANSPASSE DA FUNDAMENTALIDADE DOS DIREITOS PROLONGADOS AO CAPÍTULO PROLONGADOR. PONDERAÇÃO DIRETAMENTE CONSTITUCIONAL ENTRE BLOCOS DE BENS DE PERSONALIDADE: O BLOCO DOS DIREITOS QUE DÃO CONTEÚDO À LIBERDADE DE IMPRENSA E O BLOCO DOS DIREITOS À IMAGEM, HONRA INTIMIDADE E VIDA PRIVADA. PRECEDÊNCIA DO PRIMEIRO BLOCO. INCIDÊNCIA A POSTERIORI DO SEGUNDO BLOCO DE DIREITOS, PARA O EFEITO DE ASSEGURAR O DIREITO DE RESPOSTA E ASSENTAR RESPONSABILIDADES PENAL, CIVIL E ADMINISTRATIVA, ENTRE OUTRAS CONSEQUÊNCIAS DO PLENO GOZO DA LIBERDADE DE IMPRENSA. PECULIAR FÓRMULA CONSTITUCIONAL DE PROTEÇÃO A INTERESSES PRIVADOS QUE, MESMO INCIDINDO A POSTERIORI, ATUA SOBRE AS CAUSAS PARA INIBIR ABUSOS POR PARTE DA IMPRENSA. PROPORCIONALIDADE ENTRE LIBERDADE DE IMPRENSA E RESPONSABILIDADE CIVIL POR DANOS MORAIS E MATERIAIS A TERCEIROS. RELAÇÃO DE MÚTUA CAUSALIDADE ENTRE LIBERDADE DE IMPRENSA E DEMOCRACIA. RELAÇÃO DE INERÊNCIA ENTRE PENSAMENTO CRÍTICO E IMPRENSA LIVRE. A IMPRENSA COMO INSTÂNCIA NATURAL DE FORMAÇÃO DA OPINIÃO PÚBLICA E COMO ALTERNATIVA À VERSÃO OFICIAL DOS FATOS. PROIBIÇÃO DE MONOPOLIZAR OU OLIGOPOLIZAR ÓRGÃOS DE IMPRENSA COMO NOVO E AUTÔNOMO FATOR DE INIBIÇÃO DE ABUSOS. NÚCLEO DA LIBERDADE DE IMPRENSA E MATÉRIAS APENAS PERIFERICAMENTE DE IMPRENSA. AUTORREGULAÇÃO E REGULAÇÃO SOCIAL DA ATIVIDADE DE IMPRENSA. NÃO RECEPÇÃO EM BLOCO DA LEI N 5.250/1967 PELA NOVA ORDEM CONSTITUCIONAL. EFEITOS JURÍDICOS DA DECISÃO. PROCEDÊNCIA DA AÇÃO. (STF, Ementa do Acórdão da ADPF 130, Rel. Min. Carlos Ayres Britto, j. 30.04.2009, destacado).
\end{abstract}

Essa é a ementa redigida pelo relator, supostamente equivalente a uma versão resumida do julgamento. ${ }^{62}$ Conforme se lê nos trechos destacados, há uma inequívoca afirmação da preponderância dos direitos de liberdade de imprensa sobre os direitos de imagem, honra, intimidade e vida privada.

Entretanto, para extrair os argumentos que fundamentaram a decisão tomada pelo STF que afastou a Lei de Imprensa, o atento leitor precisa ser paciente e enfrentar as mais de 300 páginas que compõem o acórdão.

Isto porque, como já exposto anteriormente, o áudio do julgamento faz parte do acórdão (art. 93 do RISTF), registrando tudo o que foi debatido nas sessões, incluindo "o relatório, a discussão, os votos fundamentados, bem como as perguntas feitas aos advogados e suas respostas" (art. 96).

Como resultado, na ADPF 130 há 334 páginas recheadas de belos textos, frases cheias de lirismo e transcrição de clássicos da filosofia, assim estruturados:

$62 \quad$ Para conhecer os posicionamentos de cada ministro sem assistir à íntegra das sessões de julgamento televisionadas ou ler os acórdãos, é possível obter a síntese publicada pela assessoria de imprensa do STF no portal de notícias. 


\begin{tabular}{|l|l|}
\hline & Páginas \\
\hline Conteúdo & \\
\hline Ementa e acórdão & 12 \\
\hline Relatório & 8 \\
\hline Voto do Relator Min. Carlos Britto e aditamento ao voto & $\mathbf{5 8}$ \\
\hline Esclarecimento Min. Marco Aurélio e voto sem proposta & 2 \\
\hline Explicação & 2 \\
\hline Extrato de Ata & 1 \\
\hline Voto Vista Min. Menezes Direito & 10 \\
\hline Esclarecimento e Aditamento ao voto Min. Carmem Lúcia & 6 \\
\hline Voto Min. Ricardo Lewandowski & 5 \\
\hline Esclarecimento Min. Carlos Britto & 1 \\
\hline Voto Min. Joaquim Barbosa e aditamento ao voto & 15 \\
\hline Voto Min. Cezar Peluso & 3 \\
\hline Voto Min. Ellen Gracie & 6 \\
\hline Retificação de voto Min. Joaquim Barbosa & 3 \\
\hline Voto Min. Marco Aurélio & 11 \\
\hline Voto Min. Celso de Mello & $\mathbf{5 6}$ \\
\hline Explicação & 4 \\
\hline Voto Min. Gilmar Mendes & $\mathbf{6 4}$ \\
\hline Aditamento ao Voto Min. Carlos Britto & 24 \\
\hline Explicação & 2 \\
\hline Esclarecimento Min. Marco Aurélio & 2 \\
\hline Aditamento ao voto Min. Cezar Peluso & 1 \\
\hline Explicação & 2 \\
\hline Voto Min. Cármen Lúcia & 33 \\
\hline Extrato de Ata & 2 \\
\hline Total & $\mathbf{3 3 3}$ páginas \\
\hline & \\
\hline
\end{tabular}

É digno de nota que os votos de apenas 3 ministros ocupam mais da metade das 333 páginas do acórdão (Celso de Mello, 56 laudas; Gilmar Mendes, 64 laudas; Relator, Carlos Britto, 82 laudas, já somadas as dos aditamentos), explicitando claramente o enfoque nas manifestações individualizadas em detrimento ao coletivo.

Diante da grande dificuldade que seria manejar tal volume de informações toda vez que se queira referenciar o julgado, o uso apenas da ementa é tentador. No julgamento da ADPF 130, significa trocar a leitura das 334 páginas do acórdão completo por meras $\mathbf{3 3 0}$ palavras contidas na ementa.

O contraste é de tal monta que não é difícil compreender porque a síntese oficial (a Ementa) é tão relevante. ${ }^{63}$ Entretanto, problemas surgem quando, justamente, a ementa não condiz exatamente com a síntese da opinião dos ministros que participaram do julgamento. ${ }^{64}$

63 Destaque-se a importância do conteúdo preciso da decisão, pela sua eficácia erga omnes, irradiante a todo o Judiciário e Administração Pública, nos termos da Lei 9.882/99: Art. 10. Julgada a ação, far-se-á comunicação às autoridades ou aos órgãos responsáveis pela prática dos atos questionados, fixando-se as condições e o modo de interpretação e aplicação do preceito fundamental. (...) § $3^{\circ} \mathrm{A}$ decisão terá eficácia contra todos e efeito vinculante relativamente aos demais órgãos do Poder Público. (excertos da Lei 9.882/99, destacado).

64 Não obstante a crítica que se possa fazer sobre a ementa neste caso específico, cumpre destacar que, em média, nos 66 votos analisados na pesquisa de Guilherme Klafke (2010), as ementas transcrevem com fidelidade o que foi decidido pela corte. 
É o que se verá adiante.

\subsection{FUGA: OS MINISTROS EM DISSONÂNCIA}

Caberá reclamação contra o descumprimento da decisão proferida pelo Supremo Tribunal Federal, na forma do seu Regimento Interno. (Art. 13 da Lei 9.882/99, destacado).

$\mathrm{Na}$ dinâmica dos julgamentos colegiados realizados no Supremo Tribunal Federal, faltam mecanismos para garantir que a ementa sintetize a fundamentação compartilhada pela maioria.

É o que transpareceu no julgamento da Reclamação65 9428/DF, provocada a partir de uma liminar que proibia o jornal Estado de S. Paulo de publicar notícias sobre uma operação policial envolvendo o filho do Senador José Sarney.

Ao largo do mérito da reclamação - se uma decisão da justiça maranhense poderia determinar que o jornal se abstivesse de publicar dados colhidos em um processo tramitando sob segredo de justiça -, interessa especialmente a controvérsia envolvendo o contido no acórdão da ADPF 130.

Sorteado como relator da Reclamação 9.428/DF, o Min. Cezar Peluso passou a atacar a ementa do acórdão da ADPF 130, elaborada pelo Min. Carlos Britto.

O pomo da discórdia estava no trecho da ementa que alçava a liberdade de imprensa como direito fundamental superior à intimidade, honra e imagem, direitos incidentes a posteriori com relação à liberdade de imprensa, conforme destaque a seguir:

(...) PONDERAÇÃO DIRETAMENTE CONSTITUCIONAL ENTRE BLOCOS DE BENS DE PERSONALIDADE: O BLOCO DOS DIREITOS QUE DÃO CONTEÚDO À LIBERDADE DE IMPRENSA E O BLOCO DOS DIREITOS À IMAGEM, HONRA, INTIMIDADE E VIDA PRIVADA. PRECEDÊNCIA DO PRIMEIRO BLOCO. INCIDÊNCIA A POSTERIORI DO SEGUNDO BLOCO DE DIREITOS, PARA O EFEITO DE ASSEGURAR O DIREITO DE RESPOSTA E ASSENTAR RESPONSABILIDADES PENAL, CIVIL E ADMINISTRATIVA, ENTRE OUTRAS CONSEQUÊNCIAS DO PLENO GOZO DA LIBERDADE DE IMPRENSA. (STF, ADPF 130, Rel. Min. Carlos Ayres Britto, j. 30.04.2009, destacado).

O ministro Cezar Peluso atacou tais fundamentos, explicitando que a ementa do Acórdão da ADPF 130, redigido pelo Min. Relator Ayres Britto, não refletia a opinião comum dos ministros presentes naquele julgamento:

Salvas as ementas, que ao propósito refletem apenas a posição pessoal do eminente Min. Relator, não a opinião majoritária da Corte, o conteúdo semântico geral do acórdão traduz, na inteligência sistemática dos votos, o mero juízo comum de ser a lei de imprensa incompatível com a nova ordem constitucional, não chegando sequer a propor uma

65 A reclamação ao STF é um mecanismo previsto no art. 13 da Lei 9.882/99 para noticiar ao Supremo, que suas decisões vinculantes (decisões definitivas de mérito proferidas nas ADIs e ADCs nos termos do $\S 2^{\circ}$ do art. 102 da CRFB) teriam sido violadas por uma decisão de qualquer juiz ou tribunal brasileiro (ou, ainda, qualquer ato da administração pública). Constatada a violação, a decisão pode ser cassada pelo STF. 
interpretação uníssona da cláusula do art. 220, § 10, da Constituição da República, quanto à extensão da literal ressalva à legislação restritiva, que alguns votos tomaram como reserva legal qualificada. (STF, Rcl 9.428/DF, Rel. Min. Cezar Peluso, j. 10.12.2009, p. 187, destacado).

Para fundamentar seu argumento, o Min. Cezar Peluso recordou as "decisivas manifestações que relevaram a necessidade de ponderação (...) entre liberdade de imprensa e direitos da personalidade, como intimidade, honra e imagem". (STF, Rcl 9.428/DF, Rel. Min. Cezar Peluso, j. 10.12.2009, p. 187).

Além de seu próprio voto, em que destacava a preocupação da Constituição em manter o equilíbrio entre os valores da liberdade de imprensa e da dignidade da pessoa humana (fls. 122), Cezar Peluso enumera as demais opiniões contrárias ao conteúdo da ementa elaborada pelo Min. Carlos Britto, citando trechos ${ }^{66}$ de diversos votos e debates ocorridos na sessão de julgamento que, ao contrário da ementa, não atribuem à liberdade de imprensa precedência sobre os valores de imagem, honra, intimidade e vida privada.

Afirmou que os votos colocavam em evidência "o desacordo externado sobre a tese da absoluta prevalência hierárquica da liberdade de expressão frente aos demais direitos fundamentais". (STF, Rcl 9.428/DF, Rel. Min. Cezar Peluso, j. 10.12.2009, p. 187, destacado).

Por fim, o Ministro Cezar Peluso conclui que no acórdão da ADPF 130 não há posição definitiva sobre a prevalência dos direitos relativos à liberdade de imprensa sobre os direitos da personalidade (tais como intimidade, honra e imagem):

É, em suma, patente que o acórdão da ADPF no 130 não se lhe pode inferir, sequer a título de motivo determinante, uma posição vigorosa e unívoca da Corte que implique, em algum sentido, juízo decisório de impossibilidade absoluta de proteção de direitos da personalidade - tais como intimidade, honra e imagem - por parte do Poder Judiciário, em caso de contraste teórico com a liberdade de imprensa. (STF, Rcl 9.428/DF, Rel. Min. Cezar Peluso, j. 10.12.2009, p. 195/196, destacado).

Explicando a impossibilidade de se inferir tal consenso, o próprio ministro Peluso descreve o processo deliberativo do Tribunal como incapaz de sintetizar uma fundamentação comum para a decisão deliberada, uma vez que não há a formação de uma opinion of the Court:

66 Alguns trechos selecionados pelo Min. Peluso que parecem relevantes: Do Ministro Menezes, destaca a igualdade de proteção constitucional para a liberdade de expressão e dignidade da pessoa humana (fls. 86/87). Quanto ao voto da Ministra Ellen Gracie, transcreve sua discordância expressa com o relator da ADPF 130, para quem a ideia de calibração temporal ou cronológica proposta pelo Min. Carlos Britto representaria "a própria nulificação dos direitos fundamentais à intimidade, à vida privada, à imagem e à honra de terceiros" (fls. 127), ilustrando ainda que a reparação tardia da honra equivaleria ao esforço de reunir as plumas de um travesseiro, lançadas do alto de um edifício. Por fim, Cezar Peluso destaca ainda os votos dos ministros Celso de Mello, no qual a liberdade de expressão não pode amparar comportamentos delituosos, não há no sistema constitucional brasileiro direitos ou garantias que se revistam de caráter absoluto (fls. 160) e Ricardo Lewandowski, afirmando que a decisão do caso concreto deve necessariamente guiar-se pelo princípio da proporcionalidade, negando assim caráter absoluto e irrestrito à liberdade de imprensa (fls. 102/103). 
É que aqui, diferentemente do que sucede em sistemas constitucionais estrangeiros, não há, de regra, tácita e necessária concordância entre os argumentos adotados pelos Ministros, que, em essência, quando acordes, assentimos aos termos do capítulo decisório ou parte dispositiva da sentença, já nem sempre sobre os fundamentos que lhe subjazem. Não raro, e é coisa notória, colhem-se, ainda em casos de unanimidade quanto à decisão em si, públicas e irredutíveis divergências entre os fundamentos dos votos que a compõem, os quais não refletem, nem podem refletir, sobretudo para fins de caracterização de paradigmas de controle, a verdadeira opinion of the Court. (STF: Rcl 9.428/DF, Rel. Min. Cezar Peluso, j. 10.12.2009, p. 197, destacado).

Tais constatações expõem o óbvio: No julgamento da ADPF 130, as deliberações da corte não foram suficientemente profundas para debater as questões que eram agora levantadas por meio da reclamação 9.428/DF.

Sem alterações no seu processo deliberativo em plenária, é pouco provável que as decisões do Supremo venham a responder com competência às demandas de justiça.

\subsubsection{O DEBATE SOBRE O QUE HAVIA SIDO DECIDIDO}

Para aprofundar os detalhes deste debate sobre o debate (ou metadebate), a discutir o que efetivamente havia sido discutido, passa-se a transcrever a degravação do áudio da sessão ocorrida no dia 10.12.2009 (debates transcritos às fls. 214 a 228 do acórdão), destacando o debate entre o Min. Cezar Peluso, relator da Reclamação 9.428, e o Min. Carlos Ayres Britto, relator da ADPF 130.

Como já se viu, assim como em qualquer acórdão, também no julgamento desta Reclamação, a transcrição do áudio dos debates integra o acórdão. Longe de esclarecer a opinião da corte, o que há são explícitas dissonâncias.

A primeira manifestação é do Min. Carlos Britto, pedindo a palavra para defender a ementa por ele redigida para o acórdão da ADFP 130, após a leitura do voto pelo Min. Cezar Peluso:

O SENHOR MINISTRO CARLOS BRITTO (RELATOR) - Porque constou do voto do eminente Ministro Peluso a opinião, a convicção de Sua Excelência, que eu respeito, de que parte da ementa que eu redigi do acórdão refletiu apenas a minha opinião isolada e não a opinião majoritária da Corte. Então, eu estou demonstrando que não foi bem assim. À medida que a discussão se aprofundava, alguns ministros iam mais e mais se chegando para o núcleo do voto proferido pelo Relator; ou seja, por mim. (STF, Rcl 9.428/DF, Rel. Min. Cezar Peluso, j. 10.12.2009, p. 214, destacado).

A resposta do Min. Peluso tratou de afirmar que, no exercício do controle abstrato de constitucionalidade, caso da ADPF 130, não era possível estender o resultado dos debates para o caso concreto, a decisão contestada por meio da Reclamação 9.428/DF: 
O SENHOR MINISTRO CEZAR PELUSO - Se Vossa Excelência me permite, o problema é simples: todos nós estamos de acordo com a importância da liberdade da imprensa, etc. Todos nós votamos (...) A questão da reclamação é uma coisa, a meu ver, com o devido respeito, mais simples. $\mathbf{O}$ que nós temos? Temos uma decisão que, diante do dispositivo constitucional que assegura a liberdade de imprensa, aplicou outros dispositivos constitucionais, não leis revogadas, mas outros dispositivos constitucionais, que protegem a honra, a vida privada, a intimidade, etc., e normas de caráter penal, para limitar a publicação. A pergunta que se propõe é: esse tema, tal como foi posto na reclamação, foi objeto de decisão da Corte da ADPF? Não. Nem podia sê-lo, porque este é um caso concreto, e lá não havia caso concreto nenhum! O que se discutia lá era apenas se a lei era, ou não, compatível com a Constituição. E todos concordamos em que a lei era incompatível com a Constituição. (STF, Rcl 9.428/DF, Rel. Min. Cezar Peluso, j. 10.12.2009, p. 215/216, destacado).

O problema de definir o que havia sido definitivamente decidido pouco mais de sete meses antes, no julgamento da ADPF 130, ressurge com as considerações do Presidente do STF à época, Min. Gilmar Mendes:

O SENHOR MINISTRO GILMAR MENDES (PRESIDENTE) - A minha manifestação coincide com a de Vossa Excelência. Realmente, precisamos nominar o que foi objeto de decisão e aquilo que está coberto pelo efeito vinculante, sem dúvida nenhuma. Até porque houve considerações do Ministro Britto que, com certeza, não mereceram o apoio da maioria. Por exemplo, a afirmação de Sua Excelência segundo a qual não poderia haver lei regulando a imprevisibilidade nesse sentido.

O SENHOR MINISTRO CARLOS BRITTO - Mas eu não afirmei isso. (STF, Rcl 9.428/DF, Rel. Min. Cezar Peluso, j. 10.12.2009, p. 218, destacado).

Os debates passaram a envolver outros ministros, caminhando com foco no objeto da reclamação, isto é, se a decisão que proibiu a publicação jornalística envolvendo o filho do senador Sarney configurou ou não censura, nos moldes dos dispositivos da Lei de Imprensa (afastada do ordenamento jurídico com o julgamento da ADPF 130). A manifestação da Min. Ellen Gracie, em tom conciliatório, foi no sentido de que a decisão objeto da reclamação havia sido fundamentada no segredo de justiça previsto no Código de Processo Penal, matéria que não havia sido discutida na ADPF 130:

A SENHORA MINISTRA ELLEN GRACIE - (...) Apenas gostaria de relembrar que, quando discutimos a questão na ADPF, optou-se por examinar a lei como um todo e não artigo por artigo, como havia sido a proposta inaugural. Então, adotamos uma postura na linha das nossas crenças democráticas, pela liberdade de expressão, pela liberdade de imprensa, pelo direito do cidadão de obter a informação correta. De modo que, até aí, não há divergência nenhuma. Creio que agora se coloca algo diverso do que se colocou nas discussões extensas havidas no âmbito da ADPF. Ali nós estávamos contrastando a liberdade de imprensa com direitos individuais, direitos da privacidade, e ao que me parece aqui, nós devemos contrastar a liberdade de imprensa com os poderes da jurisdição. São poderes previstos no CPP, como a decretação do sigilo e do segredo de justiça. A questão não foi enfocada certamente sob esse prisma quando examinamos a ADPF. (STF, Rcl 9.428/DF, Rel. Min. Cezar Peluso, j. 10.12.2009, p. 221, destacado). 
O Min. Carlos Britto voltou a defender seu ponto de vista, afirmando que a decisão impugnada estaria fundamentada implicitamente na Lei de Imprensa, violando a decisão da ADPF 130, acirrando os ânimos da discussão com o relator da Reclamação, Min. Peluso:

O SENHOR MINISTRO CARLOS BRITTO - Ministro, eu quero concluir dizendo o seguinte: o ato atacado, vale dizer, a decisão do Tribunal de Justiça do Distrito Federal e Territórios aplicou a Lei de Imprensa. Não falou expressamente, mas aplicou de fato. (...) Ele silenciou quanto à base legal. (...) Ele se investiu num poder de censura.

O SENHOR MINISTRO CEZAR PELUSO (RELATOR) - Não, ele invocou normas constitucionais, Ministro.

O SENHOR MINISTRO CARLOS BRITTO - Que outro dispositivo dá aos juízes o poder de censura senão a Lei de Imprensa?

O SENHOR MINISTRO CEZAR PELUSO (RELATOR) - Ministro, a decisão impugnada invoca normas constitucionais.

O SENHOR MINISTRO CARLOS BRITTO - Que normas?

O SENHOR MINISTRO CEZAR PELUSO (RELATOR) - O artigo $5^{\circ}$.

O SENHOR MINISTRO CARLOS BRITTO - Mas o artigo $5^{\circ}$ não habilita o Judiciário a fazer censura.

O SENHOR MINISTRO CEZAR PELUSO (RELATOR) - Na opinião de Vossa Excelência. Esse é que é o problema.

O SENHOR MINISTRO CARLOS BRITTO - Vossa Excelência falou em ameaça. O substantivo "ameaça" não está no artigo 50, IX.

O SENHOR MINISTRO CEZAR PELUSO (RELATOR) - Ministro, não vamos alterar-nos. Vossa Excelência está dizendo que ele aplicou a Lei de Imprensa. Vossa Excelência fez afirmação de que a decisão ora impugnada aplicou a Lei de Imprensa. Eu estou dizendo a Vossa Excelência que o que ela aplicou foram as normas constitucionais.

O SENHOR MINISTRO CARLOS BRITTO - Claro que nenhum juiz, nenhum tribunal vai dizer, quando quiser impor censura à Imprensa, que estará aplicando a Lei de Imprensa. Mas não há outra base legal.

O SENHOR MINISTRO CEZAR PELUSO (RELATOR) - Ministro, isso aqui não é julgamento de paranormalidade. (STF, Rcl 9.428/DF, Rel. Min. Cezar Peluso, j. 10.12.2009, p. 222/224, destacado).

Os trechos acima transcritos expõem mais do que simples divergências de opinião entre os ministros. Para além de oposições jurídicas - em tese desejáveis, no processo dialético da busca 


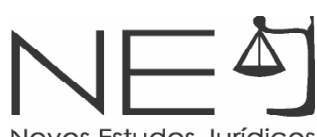

por melhores argumentos -, o debate oral explicita um procedimento viciado, incapaz de construir consensos, reforçando confrontos que levam à personalização das opiniões, exasperando o caráter individualizado das decisões tomadas.

O que se vê neste caso é a falta de clareza dos julgados e a ausência de uma síntese acurada, com um mínimo grau de confiabilidade da ementa e certeza de sua representatividade. Tais defeitos permitem a repetição de debates, em um ciclo infindável de discussões para definir o alcance do debate anterior. Decidir, afinal, o que a decisão anterior de fato decidiu, em um retrabalho pouco eficiente.

As consequências negativas com a perda de confiabilidade do STF são evidentes.

Sem alterações no seu processo deliberativo em plenária, é pouco provável que as decisões do Supremo venham a responder com competência às demandas da sociedade brasileira.

Estabelecida a pauta de problemas e dissonâncias, as alterações regimentais que podem restabelecer a harmonia são tema para um último movimento.

\title{
3. SUGESTÕES PARA NOVOS ACORDES
}

\begin{abstract}
Na realidade, o que o sistema jurídico necessita são decisões que correspondam a um maior consenso decorrente de um intenso processo de discussão e deliberação da Corte. Evidente que sempre deverá haver espaço para votos discordantes e opiniões complementares, mas a maioria deveria ser capaz de produzir uma decisão acordada, um acórdão, que representasse a opinião do Tribunal. Isto daria mais consistência a decisões judiciais de grande impacto político. (destacado). ${ }^{67}$

E para fomentar um aumento no grau de deliberação e de diálogo interno no Supremo Tribunal Federal não são necessárias reformas constitucionais, bastam algumas reformulações no seu regimento interno. Essas simples reformulações regimentais teriam talvez o potencial de produzir transformações mais profundas e benéficas do que grandes pacotes constitucionais ou legislativos. (destacado). ${ }^{68}$
\end{abstract}

O primeiro parágrafo em epígrafe, extraído do artigo de Oscar Vilhena Vieira, intitulado Supremocracia, expõe a dimensão deste desafio final, na busca de uma fórmula, um procedimento eficaz para garantir o consenso. A segunda citação, de Virgílio Afonso da Silva, indica o caminho para sugerir melhorias que levem ao aperfeiçoamento dos acórdãos do STF, de tal forma que passem a representar a opinião do tribunal e deixem de privilegiar a opinião individualizada de seus ministros.

67 VIEIRA, Oscar Vilhena. Supremocracia. Rev. Direito GV, v.4, n. 2, p. 441-463, 2008, p. 443.

68 SILVA, Virgílio Afonso da. STF, Deliberação, Diálogo e Razão Pública. Revista de Direito Administrativo (RDA), v. 250, p. 197-227, 2009, p. 220. 
O pressuposto da análise que segue é a de que os ministros são atores racionais. Isto significa dizer que, independentemente de suas convicções pessoais, seu comportamento leva em conta as regras do jogo deliberativo para ampliar as recompensas ${ }^{69}$ que possam obter.

Também é pressuposto de um ator racional, que persiga seu objetivo com o menor gasto de tempo e energia possíveis. Neste contexto, como explicar que um ministro que não seja o relator redija e leia em plenário um voto de mais de 60 laudas? A única resposta plausível é a de que, com as atuais regras procedimentais, a apresentação de um voto longo seja a melhor forma de obter os benefícios esperados, sejam lá quais forem.

Nas regras atuais do Regimento Interno, a harmonia do conjunto é prejudicada pelo incentivo ao brilho individual, ou, seguindo a metáfora musical, o verdadeiro solo no qual o tema está integralmente nas mãos de um único músico. Os apontamentos que seguem buscam diminuir os incentivos ao comportamento individual, aumentando a recompensa aos magistrados que atuarem em conjunto, privilegiando o espírito de equipe.

\subsection{O RELATOR DÁ O TOM...}

O primeiro a fazer solo é o relator. Seu destaque é evidente: como já se descreveu anteriormente, designado pela inquestionável alea divina, o relator concentra poderes sobre como e quando a discussão será realizada. Além de tais privilégios, evidente vantagem para impor sua decisão, ocupa espaço de elevado prestígio no precedente. Ao citar uma decisão, é praxe no meio jurídico consignar quem foi o relator da decisão, tal como se adquirisse direitos de paternidade do julgado.

Quanto a estas primeiras constatações, sugerem-se alterações regimentais para que o relator passe da figura de um compositor para a de um membro da orquestra, fazendo, quando muito, um solo inicial para relatar o caso aos colegas.

O relatório, no formato atual, trata apenas das normas envolvidas e das alegações do autor como suficientes para cingir o objeto do julgamento.

Seria mais construtivo, entretanto, que também fixasse as questões a serem debatidas, estabelecendo os pontos de controvérsia sobre os quais se desenrolarão os debates, como sugere Guilherme Klafke:

69 A discussão sobre o que seriam recompensas pode ser encontrada em detalhes em Richard Posner na obra How Judges Think, 2008 , Harvard University Press. Nela, Posner enumera vários objetivos perseguidos pelos magistrados em sua atuação, como, por exemplo, o reconhecimento público, o prestígio entre os colegas e a própria prevalência do que acreditam ser a decisão mais justa. 
(...) a falta de uma delimitação precisa sobre o que será julgado, mesmo que feita pela própria Corte em uma reunião prévia, possibilita que os ministros abordem o caso sob diferentes ópticas, dificultando uma decisão coesa. (...) Como visto, os Relatórios são estruturados sempre de uma forma adversarial. Geralmente, são apresentados os argumentos do autor e seus pedidos. Por algumas vezes, são expostos também os argumentos da defesa. Todavia, em nenhum momento se determina exatamente quais os "passos" que a Corte deve seguir para resolver o caso. Nenhuma das partes está preocupada em fixar os pontos sobre os quais se assenta a controvérsia, muitas vezes por estratégia "advocatícia" do autor e da defesa. ${ }^{70}$

Assim, seria relevante que o relator convocasse uma reunião prévia, para fixar os pontos controvertidos, delimitando as questões a serem analisadas, tal qual o despacho saneador previsto no art. 451 do CPC/1973 ou do art. 357 do CPC/2015. ${ }^{11}$ Embora trate de questões de prova em instrução processual, tal delimitação de temas controvertidos serve de baliza para a busca por uma solução em um conflito jurídico. Admitir que os ministros do STF se comportam, muitas vezes, como partes adversárias de um processo é uma ótima maneira de procurar soluções em busca do consenso.

\section{2... REGE OS ENSAIOS...}

Uma forma de prestigiar a deliberação interna no tribunal seria a realização de ensaios, isto é, reuniões prévias à sessão de julgamento. Na regra atual (art. 135 do RISTF), como há apenas uma sessão que concentra a leitura do relatório, dos debates e dos votos, os ministros são levados a trazer votos prontos, de tal modo que suas posições são fortalecidas:

Ter um voto é uma grande fonte de poder na Corte, o que aumenta as chances de que o ministro não ceda perante as investidas de outro. Por outro lado, a possibilidade de conceber uma fundamentação própria faz com que os ministros não se preocupem em manter a linha de raciocínio dos votos anteriores. ${ }^{72}$

Ainda, o voto pronto é um desestímulo ao debate, pois ceder em algum ponto à opinião de outros ministros significa ter o custo de reelaborar a decisão já tomada, como indica o levantamento de Guilherme Klafke:

Portanto, verifica-se, a partir dos acórdãos pesquisados, que as manifestações que se seguem às do relator do caso ou acrescentam fundamentos que não são aproveitados na decisão final da Corte, ou se limitam a reforçar aspectos que já foram tratados nos votos anteriores. ${ }^{73}$

70 KLAFKE, Guilherme Forma. Vícios no processo decisório do Supremo Tribunal Federal. Monografia (especialização) em Direito Público. São Paulo: SBDP, 2010, p. 86-87.

71 CPC/1973, art. 451. "Ao iniciar a instrução, o juiz, ouvidas as partes, fixará os pontos controvertidos sobre que incidirá a prova." CPC/2015 art. 357. "Não ocorrendo nenhuma das hipóteses deste capítulo, deverá o juiz, em decisão de saneamento e de organização do processo: (...) II - delimitar as questões de fato sobre as quais recairá a atividade probatória, especificando os meios de prova admitidos; (...) IV - delimitar as questões de direito relevantes para a decisão do mérito;

72 KLAFKE, Guilherme Forma. Vícios no processo decisório do Supremo Tribunal Federal. Monografia (especialização) em Direito Público. São Paulo: SBDP, 2010, p. 117.

73 KLAFKE, Guilherme Forma. Vícios no processo decisório do Supremo Tribunal Federal. Monografia (especialização) em Direito Público. São Paulo: SBDP, 2010, p. 88-89. 
O julgamento imediato, após a leitura dos votos, não permite encontrar resposta para eventuais questões pertinentes que tenham surgido e que demandem estudos aprofundados:

Outros tribunais possuem pelo menos dois momentos para o julgamento. Há um específico para a deliberação e outro específico para que se profira a decisão final. Isso evita que os julgadores se sintam pressionados a resolver as questões imediatamente, conferindo-lhes tempo para refletir sobre o caso e, se desejarem, alterarem sua posição. ${ }^{74}$

Ademais, caso a elaboração dos votos fosse realizada após os debates, o estímulo seria o inverso: a tendência de incorporar ao voto as boas ideias ouvidas na sessão seria maior, aproximando as decisões em seus fundamentos.

\section{3 ... MAS NÃO DITA A MÚSICA}

Outra alteração relevante seria a forma de apresentação do voto do relator. Na forma do art. $21, \S 3^{\circ}$ do RISTF, o relator deve pedir dia para julgamento dos processos sob sua relatoria, o que é feito quando tem seu voto pronto, já finalizado.

Entretanto, mais construtivo seria que o relator apresentasse um voto em construção, com um leque de soluções, em vez de uma só, predeterminadas. De acordo com Guilherme Klafke, tal solução já foi parcialmente adotada no julgamento da ADI 3854, inspirada nas Cortes Constitucionais da Itália e da Áustria:

Uma terceira ideia pode ser extraída da conjugação do voto do Min. Cezar Peluso, no Caso dos tetos de remuneração da magistratura (ADI 3854-3/DF), com as experiências estrangeiras. Trata-se da proposta de que o Relator não traga um voto pronto, uma solução final, mas um leque de opções, de alternativas, às quais os outros ministros poderiam aderir ou não. Na Itália, o Relator é responsável por examinar os aspectos mais importantes da causa e propor algumas soluções. No Tribunal austríaco, o Relator apresenta um esboço de decisão sobre o qual a Corte trabalha. O que proponho, então, é que o Relator, sem prejuízo de optar por uma ou outra solução, efetivamente traga várias alternativas que, embora diferentes, mantenham-se dentro de sua linha de raciocínio. ${ }^{75}$

Com o leque de opções, o relator passaria a atuar como um mediador, consultando de forma aberta os colegas sobre o problema a ser resolvido, deixando de se apresentar como fornecedor de um caminho único, contra o qual o ministro que encontre outra via se coloca na posição de dissidente.

$74 \quad$ KLAFKE, Guilherme Forma. Vícios no processo decisório do Supremo Tribunal Federal. Monografia (especialização) em Direito Público. São Paulo: SBDP, 2010, p. 124

75 KLAFKE, Guilherme Forma. Vícios no processo decisório do Supremo Tribunal Federal. Monografia (especialização) em Direito Público. São Paulo: SBDP, 2010, p. 124. 


\section{CONSIDERAÇÕES FINAIS}

Diante de tais propostas, é importante destacar os benefícios da polifonia: Consenso não é sinônimo de unanimidade.

Não se trata da imposição de opiniões, de forma mecânica com a simples contagem de votos - o que tem ocorrido em julgamentos polêmicos, vide o julgamento em dezembro de 2017 das Ações Declaratórias de Constitucionalidade (ADCs) 43 e 44, do Partido Nacional Ecológico (PEN) e do Conselho Federal da Ordem dos Advogados do Brasil (OAB), que versam sobre a autorização para execução provisória da pena após decisão em segunda instância. É importante esclarecer que não deve haver espaço para tendências totalitárias e tampouco se defende a hegemonia de pensamento único no Supremo Tribunal Federal. ${ }^{76}$

A construção que se propõe parte do pressuposto de que a multiplicidade de vozes, a polifonia, é fundamental para o amadurecimento de ideias e a busca por fundamentos mais sólidos, como no julgamento, em 2011, acerca das uniões homoafetivas (ADI 4277 e Arguição de Descumprimento de Preceito Fundamental (ADPF) 132), no qual embora tenha ocorrido o consenso para a procedência da ação e para o resultado prático da decisão, os fundamentos para cada voto foram diversos, adotando referencias teóricos e justificativas distintas. ${ }^{77}$

Neste sentido, cumpre destacar a importância do voto vencido, a partir da curiosa constatação feita por Marcela Mattiuzzo, relatando a alta incidência desta posição por parte do Min. Marco Aurélio: "O Ministro Marco Aurélio profere muito mais votos classificados como vencidos que os demais membros da Corte (mais de $50 \%$ do total), sendo que o segundo ministro que mais se manifestou como vencido, Eros Grau, atinge pouco mais de 10\%".78

Entretanto, não obstante a aparente inutilidade de registro da posição vencida, a pesquisadora identificou que a posição discordante contribuía para dotar de maior consistência a corrente majoritária, pois levava os ministros ao debate para responder às oposições do voto contrário, colacionando maiores explicações e argumentos para fortalecer o voto vencedor.

\footnotetext{
76 Cumpre esclarecer que o presente artigo adota o "consenso" como construção dialógica em busca de um denominador comum nos posicionamentos dos ministros do Supremo Tribunal Federal. Não se defende, de maneira alguma, uma visão "totalitária" em que haveria uma única solução correta, na qual qualquer voz dissonante seria rechaçada. Assim, posiciona-se radicalmente contra as tendências totalitárias nos julgamentos, como as debatidas por Hannah Arendt no seu relato sobre o julgamento de Adolf Eichman em "Eichman em Jerusalém", na qual, após descrever a ausência de vozes dissonantes, afirma: "Em resumo, o tribunal havia sido injusto, o julgamento tinha sido injusto". (ARENDT, 1999, p. 270).

77 MOREIRA, Izabel Rosa. Diversidade sexual como direito fundamental: o reconhecimento jurídico da homoafetividade no Brasil. Curitiba: Juruá, 2015.

78 MATTIUZZO, Marcela. Voto vencido, fundamentação diversa e fundamentação complementar: Um estudo sobre deliberação no supremo tribunal federal. Monografia (especialização) em Direito Público. São Paulo: SBDP, 2011, p. 65.
} 
Posturas como esta do ministro Marco Aurélio, as quais muitas vezes são criticadas por não fornecerem teses vencidas fortes, parecem auxiliar na construção de teses vencedoras mais consistentes. $\mathrm{O}$ fato de o ministro apresentar um contraponto força os demais a se debruçarem sobre o tema e tentarem fornecer melhores argumentos para sustentar suas posições. ${ }^{79}$

No mesmo sentido, é a constatação de Guilherme Klafke sobre votos orais, proferidos no calor dos debates:

Os votos em debates, i.e., aqueles proferidos em meio a apartes de outros ministros, trazem uma surpresa interessante. $O$ interesse não reside tanto no número deles (treze), mas sim na relevância que, em geral, eles tiveram para o julgamento. (...) 0 que se verifica, nos quatro casos, é que esse tipo de participação é muito importante porque, em geral, é acompanhada de um pedido de explicações a outro ministro. Isso leva a uma clareza maior de fundamentos e também à possibilidade de uma adesão mais firme à posição do colega. Portanto, é possível levantar a hipótese de que quanto mais debates ocorrerem numa sessão, maiores as chances de que as premissas dos votos sejam esclarecidas e, consequentemente, maiores as possibilidades de que uma fundamentação seja rebatida ou apoiada. Por isso, a presença dos ministros também se torna um fator essencial para a qualidade da decisão, como pode ser verificado na análise do caso do piso salarial dos professores (ADI-MC 4167). (destacado). ${ }^{80}$

Finalmente, retomando a metáfora musical, cabe ao processo deliberativo do STF uma aproximação com as composições de Johann Sebastian Bach em sua Arte da Fuga, de 1750. Nestas obras, a música é resultado da síntese harmoniosa de diversas vozes que, apesar de descrever caminhos melódicos distintos, são capazes de criar um todo harmônico e consonante.

É o que falta aos acórdãos do Supremo Tribunal Federal: Mecanismos para que as vozes distintas alcancem a síntese harmoniosa de seu entendimento.

\section{REFERÊNCIAIS DAS FONTES CITADAS}

AMORIM NETO, Octavio; COX, Gary W. \& MCCUBBINS, Mathew D. Agenda Power in Brazil's Câmara dos Deputados, 1989-98. World Politics, v. 55, n. 4, p. 550-578, 2003. Disponível em: < http://journals.cambridge.org/action/displayAbst ract?fromPage $=$ online\&aid $=7610864 \&$ fileld $=$ S0043887100006158 $>$. Acesso em: 22 set. 2017 .

ARENDT, Hannah. Eichman em Jerusalém: Um relato sobre a banalidade do mal. Trad. José Rubens Siqueira. São Paulo: Companhia das Letras, 1999.

CARVALHO, Luiz Maklouf. Data Venia, O Supremo - O Supremo, quousque tandem? Piauí, v. 4, n. 48, p. 34-41, 2010. Disponível em: <http://revistapiaui.estadao.com.br/edicao-48/questoes-juridicas/o-supremo-quousque-tandem>. Acesso em: 30 mai. 2017.

KLAFKE, Guilherme Forma. Vícios no processo decisório do Supremo Tribunal Federal. Monografia (especialização) em Direito Público. São Paulo: SBDP, 2010. Disponível em: <www.sbdp.org.br/arquivos/monografia/164_Monografia\%20 Guilherme\%20Klafke.pdf>. Acesso em: 12 ago. 2017.

79 MATTIUZZO, Marcela. Voto vencido, fundamentação diversa e fundamentação complementar: Um estudo sobre deliberação no supremo tribunal federal. Monografia (especialização) em Direito Público. São Paulo: SBDP, 2011, p. 65.

80 KLAFKE, Guilherme Forma. Vícios no processo decisório do Supremo Tribunal Federal. Monografia (especialização) em Direito Público. São Paulo: SBDP, 2010, p. 89-91. 
MATTIUZZO, Marcela. Voto vencido, fundamentação diversa e fundamentação complementar: Um estudo sobre deliberação no supremo tribunal federal. Monografia (especialização) em Direito Público. São Paulo: SBDP, 2011. Disponível em: <www.sbdp.org.br/monografias_ver.php?idConteudo=184>. Acesso em: 15 ago. 2017.

MENDES, Conrado Hübner. Direitos fundamentais, separação de poderes e deliberação. Tese (doutorado) em Ciência Política. São Paulo: USP, 2008. Disponível em: <www.teses.usp.br/teses/disponiveis/8/8131/tde-05122008-162952/pt-br. php>. Acesso em: 10 set. 2017.

Sessão de leitura no STF. Folha de São Paulo. São Paulo, 05 de outubro de 2010. Tendências/Debates, p. 3. Disponível em: <http://bit.ly/1NKmAWo>. Acesso em: 22 set. 2017.

METZLER, J. B. Musik um uns: Für den Kursunterricht in Klasse 11. 2. ed. Stuttgart: Poeschel Verlag, 1991.

MOREIRA, Izabel Rosa. Diversidade sexual como direito fundamental: o reconhecimento jurídico da homoafetividade no Brasil. Curitiba: Juruá, 2015.

NADELMANN, Kurt H. The Judicial Dissent: Publication v. Secrecy. The American Journal of Comparative Law, v. 8, n. 4, p. 415-432, 1959.

PEREIRA, Saylon Alves. Os pedidos de vista no supremo tribunal federal: uma análise quantitativa nos casos de controle concentrado de constitucionalidade. Monografia (especialização) em Direito Público. São Paulo: SBDP, 2010. Disponível em: <www.sbdp.org.br/monografias_ver.php?idConteudo=177>. Acesso em: 22 ago. 2017.

RODRIGUEZ, José Rodrigo. Sobre a Qualidade da Jurisdição: Fundamentação das Sentenças, Justiça Opinativa e Luta pela Justificação no Direito Brasileiro Contemporâneo. Texto apresentado no Núcleo de Constitucionalismo e Democracia do Programa de Pós-Graduação em Direito da UFPR, 2011.

SCHOENBERG, Arnold. Harmonia. Trad. Marden Maluf. São Paulo: Unesp, 2001.

SILVA, Virgílio Afonso da. STF, Deliberação, Diálogo e Razão Pública. Revista de Direito Administrativo (RDA), v. 250, p. 197-227, 2009. Disponível em: <http://bibliotecadigital.fgv.br/ojs/index.php/rda/article/view/4144>. Acesso em: 10 jul. 2017.

TRAGTENBERG, Lívio. Contraponto: uma arte de compor. 2. ed. São Paulo: EdUSP, 2002.

VALE, André Rufino do. É preciso repensar a deliberação no Supremo Tribunal Federal. Revista Consultor Jurídico [online], 2014. Disponível em: <www.conjur.com.br/2014-fev-01/observatorio-constitucional-preciso-repensar-deliberacao-stf>. Acesso em: 08 ago. 2017.

VIEIRA, Oscar Vilhena. Supremocracia. Rev. Direito GV, v.4, n. 2, p. 441-463, 2008. Disponível em: <http://dx.doi. org/10.1590/S1808-24322008000200005>. Acesso em: 20 set. 2017.

VOJVODIC, Adriana de Moraes; MACHADO, Ana Mara França; CARDOSO, Evorah Lusci Costa. Escrevendo um romance, primeiro capítulo: precedentes e processo decisório no STF. Rev. direito GV, v. 5, n. 1, p. 21-44, 2009. Disponível em: <http://dx.doi.org/10.1590/S1808-24322009000100002 >. Acesso em: 12 set. 2017.

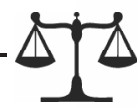

RECEBIDO EM: 03/08/2019

APROVADO EM: 25/11/2019 